\title{
Full Vaccination Coverage and Associated Factors Among 12-to-23-Month Children at Assosa Town, Western Ethiopia, 2020
}

\author{
Melkamu Senbeta Jimma (iD) \\ Fisha Alebel GebreEyesus (iD) ${ }^{2}$ \\ Ermias Sisay Chanie (ID $^{3}$ \\ Mekdess Wesenyelh Delelegn ${ }^{4}$ \\ 'Department of Nursing, Faculty of \\ Health Science, Assosa University, \\ Assosa, Ethiopia; ${ }^{2}$ Department of \\ Nursing, Colleges of Medicine and Health \\ Science, Wolkite University, Wolkite, \\ Ethiopia; ${ }^{3}$ Department of Nursing, \\ Colleges of Health Sciences, Debre Tabor \\ University, Debre Tabor, Ethiopia; \\ ${ }^{4}$ Department of Pediatrics and Child \\ Health Nursing, School of Nursing, \\ Colleges of Medicine and Health \\ Sciences, University of Gondar, Gondar, \\ Ethiopia
}

Correspondence: Melkamu Senbeta Jimma

Department of Nursing, Faculty of Health Science, Assosa University, PO Box 18,

Assosa, Ethiopia

Tel +251920464234

Email melkasenI2@gmaail.com
Introduction: Vaccination means the injection of a killed microbe to stimulate the immune system against the microbe, which prevents communicable diseases. It's the most important and cost-effective public health intervention to reduce child mortality and morbidity. Ethiopian national full vaccination coverage is $43 \%$. This research aimed to assess full vaccination coverage and associated factors among 12-to-23-month children at Assosa Town. Methods: A community-based cross-sectional study was conducted among children aged of 12 to 23 months from November to December 2020. Assosa town has two woredas. Each woreda has five kebeles. By using lottery method, five kebeles were selected from two woredas. Systematic sampling technique was used for sampling. The total sample size was 372. It was calculated by the proportionate allocation method. Questioners were used to collect data by the observation of vaccination caring and mother interviewing. Data were entered into SPSS and analyzed. Multivariance analysis was used by considering a 95\% confidence interval. Variables whose p-value less than 0.05 were identified as significant.

Results: The respondent rate of this study was 372 (100\%). Of the total respondents, 338 (90.8\%) were females and $34(9.1 \%)$ of them were males. The coverage of full, partial, and non-vaccination is $71.77 \%, 16.67 \%$, and $11.56 \%$, respectively. Based on multivariate logistic regression analysis, child age $[\mathrm{AOR}=2.7,95 \% \mathrm{CI}:(1.36,5.4)]$, no antenatal care visit $[\mathrm{AOR}=0.41,95 \% \mathrm{CI}:(0.24,0.71)]$ and fear of covid 19 at health institutions [AOR=3.5, 95\% CI: $(2,6)]$ were identified as significant variables. There are major identified factors for partial and non-vaccination.

Conclusion: Coverage of full, partial, and non-vaccination was $71.77 \%, 16.67 \%$, and $11.56 \%$, respectively. Child age, no antenatal care visit, and fear of covid 19 at health institutions were significant variables. Fear of covid-19 is the commonest factor for partial and non-vaccination.

Keywords: Assosa, factors, full vaccination, 12-to-23 months

\section{Introduction}

Immunization is the process whereby a person is made resistant to an infectious disease, typically usually by the administration of a vaccine. ${ }^{1}$

Immunization of children against preventable diseases is crucial to decrease childhood mortality and morbidity across the globe. Making and improving routine immunization services are the best options for prevention and control of vaccine preventable diseases. For that reason, the expanded program of immunization (EPI) was launched in 1974 as a global ${ }^{2}$ and in 1980 it was launched by Ethiopian government Federal Ministry of Health $(\mathrm{FMoH})$, with the goal of increasing immunization coverage by $10 \%$ annually. ${ }^{3}$ 
Universal immunization of children for six common vaccine-preventable diseases, namely, tuberculosis, diphtheria, whooping cough (pertussis), tetanus, polio, and measles, is crucial in reducing infant and child mortality. ${ }^{4}$ Other added childhood vaccines given in Ethiopia protect against hepatitis $\mathrm{B}$, Hib, PCV, and rotavirus. $^{4}$

WHO has estimated that around $29 \%$ of under-fiveyear deaths could be prevented with existing vaccines, which prevents between 2 and 3 million deaths each year globally. ${ }^{5}$ It is considered as one of the most preferable and cost-effective ways of all health interventions. It also prevents incapacitating illness and complications and saves the lives of millions every year. ${ }^{6}$ Given the shortterm and long-term impact of declining immunization rates on child health, there is a need to actively monitor vaccination practices in low-resource settings to ensure there are no disruptions in service delivery. ${ }^{7}$

Children without vaccination and child/pediatric age in Africa are children at risk for the worst social and health outcome. $^{8}$

Various reports vilified that the infant mortality rate is more common in low-income countries. Most children living in sub-Saharan Africa die every 12 months from communicable diseases that can be prevented through vaccination. For example, evidence of WHO from 2001 to 2008 reviled that around 9 million child deaths worldwide as a result of vaccine-preventable diseases, a higher proportion occurred in sub-Saharan Africa, which was 4.4 million. ${ }^{9}$

In 2018, complete immunization coverage at Ethiopian national level and Amhara region was 38.5\% and 45.8\%, respectively. ${ }^{10}$

According to EDHS 2019, full immunization coverage is $43 \%{ }^{4}$ and other national research reviews conducted from 2003 to August 2019 reviled that full immunization coverage in Ethiopia was $58.92 \%{ }^{11}$

Therefore, accurate immunization evidence is essential for decision-makers of the immunization program to track and improve its performance. ${ }^{10}$

Thus, this study would fill the existing information gap and help decision-makers and policy makers, regional and national programmers, and service providers to overcome challenges and improve the coverage of child vaccinations, which help fight vaccine-preventable diseases. Moreover, it would be a guide for effective utilization of resources by providing relevant and evidence-based recommendations for addressing issues related to vaccination. ${ }^{12}$
There for conducting this research helped to test the new variables incorporated, which helps as a baseline for other researchers.

\section{Objectives}

\section{General Objective}

To assess full vaccination coverage and associated factors among 12-to-23-month children at Assosa Town, Western, Ethiopia, 2020.

\section{Specific Objective}

To assess full vaccination coverage among 12-to-23-month children at Assosa Town, Western, Ethiopia, 2020.

To determine factors associated with full vaccination coverage among 12-to-23-month children at Assosa town, Western, Ethiopia, 2020.

\section{Methods and Materials}

\section{Study Area and Design}

The study was conducted from November $01 / 2020$ to December 10/2020 in Assosa town, Benishangul Gumuz region, Western Ethiopia. Assosa town is situated $662 \mathrm{~km}$ north western Addis Ababa and the town has two Woredas and it has one governmental hospital, two health centres, and eight private clinics. Women of childbearing age (1549) were 7867 and a total of 5291 were children under 5 years of age. From these two woredas five kebeles were selected. From woreda one, two kebeles were selected and which has around 1497 children. From woreda two, three kebeles were selected and which has around 1381 children with the age range of 12 to 23 months.

\section{Source Population}

All households which have children 12 to 23 months who were living in Assosa Zone, Assosa woreda Town.

\section{Study Population}

The study population was children from 12 to 23 months of age from five randomly selected kebeles in Assosa town.

\section{Sample Size Determination}

The sample sizes required were determined based on a single proportion population formula with the assumption of 5\% marginal error (d), 95\% confidence level (z), and the estimated proportion of full vaccine coverage is $48.8 \%$ which is conducted in Oromia, Serbo Town. ${ }^{13}$ 


$$
\begin{aligned}
& \text { no }=Z_{a / 2}^{2} p(1-p) \\
& d^{2} \\
& (1.96)^{2} 0.488(1-0.488) \\
& 0.05^{2}
\end{aligned}
$$

Based on the specification of the above formula, we got 383. The total number of eligible children below 2 years of age in the district is 2878 which is less than 10,000 . Therefore, we were using the finite population correction formula;

$\mathrm{nf}=$ no $/ 1+$ no, no $=$ initial, sample size $=384$

$\mathrm{N} \mathrm{n} \mathrm{f}=$ final sample size $=$ required

$\mathrm{N}=$ total number of eligible children $=2854$

By using the formula, $\mathrm{nf}=338$. Then we were added a $10 \%$ non-respondent rate which gave the final sample size of 372 , so the final sample size was of 372 .

\section{Sampling Techniques and Procedures}

There were two Woredas in Assosa Town. These are Woreda one and Woreda two. Each Woreda has five Kebeles. From Woreda one, two kebeles and from Woreda two, three Kebeles were selected by using the lottery method. From Woreda one, Kebele one and Kebele three had target groups of 309 and 284, respectively. From Woreda two, Kebele two, Kebele four, and Kebele five had target groups of 295, 276, and 280, respectively.

By using proportionate allocation method, $\mathrm{K}$ value was approximately 5 for all five kebeles. Finally, systematic sampling was used to collect data every five intervals.

\section{Inclusion Criteria and Exclusion Criteria Inclusion Criteria}

Children with their mother or caretaker living in Assosa town for at least 12 months

The inclusion criteria were all mothers or caregivers who had a child aged from 12 to 23 months. And caretakers aged 15 years and above were included in this study.

\section{Exclusion Criteria}

Mentally or critically ill mothers or care children with their mother or caretakers who had not been living in the study area for at least 12 months to the date of data collection. And caretakers aged below 15 years were excluded from the study.

\section{Data Collection Procedure}

Questionnaires were prepared in English and then translated to Amharic and translated back to English for accuracy and consistency. It was collected by two trained BSc Nursing professionals.

Data on vaccination history were collected from the available immunization cards. Mothers or care takers of the child were asked for presence of the card. Then the information found on the immunization cards were recorded accordingly.

\section{Data Quality Control and Analysis}

The Questionnaires were prepared in English and translated in to Amharic by ourselves and then translated back to English by another translator to compare the consistency. A two-day training was given for 2 BSc Nursing professionals who had a training certificate before and experience with the immunization services. Before data collection, the questionnaire was pretested on $5 \%$ of mothers in Bambasi Woreda and the findings were excluded from the main study. Data entry, cleaning, coding, and analysing were performed by using SPSS version

22 statistical software. Reasons for vaccination failure among partial and non-vaccination were analysed by descriptive statistics for observation.

\section{Operational Definitions}

Fully Vaccinated/Complete Immunization

A child from 12- to 23-month-old who received one dose of BCG, at least three doses of pentavalent, four doses of OPV/IPV, two doses of Rota, and one dose of measles vaccine by card plus mother history.

\section{Partially/Incompletely Immunized}

A child 12 to 23 old who had missed anyone vaccine out of the ten vaccines.

\section{Non-Vaccinated/Immunized}

A child 12 to 23 old who did not receive any vaccine.

\section{Caretaker}

It is the most responsible person that provides child care for the 12 to 23 old children whose biological mother could not provide intimate care.

\section{Kebele}

Is the smallest administrative area of Ethiopia.

\section{Study Variables}

Dependent Variable

Full vaccination/complete immunization 


\section{Independent Variables}

\section{Socio-Demographic Variables}

Age, sex, marital status of the mother, religion, number of children and ethnicity, monthly family income, occupation, educational status of the family, residence, birth order, and place of birth of the index children

\section{Maternal Health Care Utilization and Related}

Facility of vaccination, time to reach health facility, fear of covid 19 at health institutions.

\section{Availability and Accessibility of Vaccination Service}

Attained ANC visit, Number of ANC visits, Received TT Vaccine, Number of TT injections and place of delivery.

Knowledge of Mothers/Caretakers on Vaccine and Vaccine-Preventable Disease

Heard about vaccination, the way of information heard, objectives of vaccination, numbers of sessions for full vaccination, age of child to begin vaccination, vaccination will make your child sick, you bring a sick child for vaccination, and your child take any vaccination.

\section{Ethical Consideration}

The ethical clearance was secured from the Internal review board of Assosa University on September 6/2020 with Ref. No: ASU/IRB/007/2020. An official support letter from Department of Public Health were written to the administrative body of Assosa town health office. It was conducted in accordance with the Declaration of Helsinki. Data collections were started after permissions were obtained from the town health office and municipality. Study participants were asked their informed consent before asking for any information. The objectives of the study were explained to every participant and were asked to give information only after they gave their written informed consent. No person was obligated to participate in the study without his or her consent. Also, participants under 18 years of age were approved by the ethics committee to provide informed consent on their own behalf.

\section{Results}

Three hundred and seventy-two (372) mothers were eligible to participate in the study and we had a $100 \%$ respondent rate.

\section{Sociodemographic Characteristics of the Study Population}

From the total of 372 respondents, $338(90.9 \%)$ were female and $40(9.1 \%)$ of them were male. From total mothers, 10 (2.7\%), 85 (22.8\%), 126 (33.9\%), and 151 (40.6\%) were aged found in the age range of 15-19, $20-24,25-30$ and above 30 , respectively.

Around 242 (65.1\%) of the mother's educational status were secondary school and above, whereas most of the mother's income levels were greater than 3000 thousand Ethiopian Birr and it accounts 205 (55.1\%) (Table 1).

Table I Socio, Demographic, and Economic Status of the Respondents at Assosa Town, Ethiopia, 2020

\begin{tabular}{|c|c|c|c|}
\hline Variables & Categories & Frequency & $\%$ \\
\hline \multirow[t]{2}{*}{ Respondent Sex } & Male & 34 & 9.1 \\
\hline & Female & 338 & 90.9 \\
\hline \multirow[t]{4}{*}{ Respondent Religion } & Orthodox & 179 & 48.1 \\
\hline & Muslim & 135 & 36.3 \\
\hline & Protestant & 54 & 14.5 \\
\hline & Other & 4 & 1.1 \\
\hline \multirow[t]{4}{*}{ Mother age } & $15-19$ & 10 & 2.7 \\
\hline & $20-24$ & 85 & 22.8 \\
\hline & $25-30$ & 126 & 33.9 \\
\hline & $>30$ & $|5|$ & 40.6 \\
\hline \multirow[t]{4}{*}{ Mothers' education } & Cannot read and write & 18 & 4.8 \\
\hline & Read and write & 47 & 12.6 \\
\hline & Primary & 65 & 17.5 \\
\hline & Secondary and above & 242 & 65.1 \\
\hline \multirow[t]{4}{*}{ Marital status } & Single & 18 & 4.8 \\
\hline & Married & 303 & 81.5 \\
\hline & Divorced & 21 & 5.6 \\
\hline & Widowed & 30 & 8.1 \\
\hline \multirow[t]{6}{*}{ Mother Occupation } & Farmer & 68 & 18.3 \\
\hline & Pastoralist & 18 & 4.8 \\
\hline & Merchant & 78 & 21.0 \\
\hline & Daily worker & 29 & 7.8 \\
\hline & Government worker & 178 & 47.8 \\
\hline & Other & I & 0.3 \\
\hline \multirow[t]{5}{*}{ Ethnicity } & Oromo & 119 & 32 \\
\hline & Amhara & $13 \mid$ & 35.2 \\
\hline & Berta & 66 & 17.7 \\
\hline & Gumuz & 44 & 11.8 \\
\hline & Other & 12 & 3.2 \\
\hline \multirow[t]{3}{*}{ Monthly income } & $<1500$ & 23 & 6.2 \\
\hline & $|50|-3000$ & 144 & 38.7 \\
\hline & $>3000$ & 205 & 55.1 \\
\hline
\end{tabular}




\section{Sociodemographic Characteristics of Child}

Approximately the same percentage of sex is $49.5 \%, 50.5 \%$ are male and females, respectively. And the percentage of child age who are $>12$ months accounts $57 \%$, see (Table 2).

\section{Maternal Health Care Utilization and Related}

From the 372 respondents, 369 (99.2\%) of them had access to vaccination and the rest of them did not have access. And around 278 (74.7\%) of all respondents had fear of covid 19 at health institutions during the time of vaccination (Table 3 ).

\section{Availability and Accessibility of Vaccination Service}

Two hundred ninety (78\%) mothers were attending their ANC visit during their pregnancy time. And 276

Table 2 Sociodemographic Characteristics of Children Among 12 to 23 Months in Assosa Town, Ethiopia, 2020

\begin{tabular}{|l|l|l|l|}
\hline Variables & Categories & Frequency & $\%$ \\
\hline Child sex & Male & 184 & 49.5 \\
& Female & 188 & 50.5 \\
\hline Child age & $12-15$ months & 184 & 49.5 \\
& $16-19$ months & 114 & 30.6 \\
& $20-23$ months & 74 & 19.9 \\
\hline Number of siblings & $0-2$ & 167 & 44.9 \\
& $3-5$ & 186 & 50 \\
& $>5$ & 19 & 5.1 \\
\hline Birth spacing & $<2$ years & 194 & 52.2 \\
& $>2$ years & 178 & 47.8 \\
\hline
\end{tabular}

Table 3 Maternal Health Care Utilization and Related Characteristics Among 12 to 23 Months at Assosa Town, Ethiopia, 2020

\begin{tabular}{|l|l|l|l|}
\hline Variables & Categories & Frequency & $\%$ \\
\hline $\begin{array}{l}\text { Is there health facility access } \\
\text { for vaccination }\end{array}$ & $\begin{array}{l}\text { Yes } \\
\text { No }\end{array}$ & $\begin{array}{l}369 \\
3\end{array}$ & $\begin{array}{l}99.2 \\
0.8\end{array}$ \\
\hline Time to reach to health facility & $\begin{array}{l}<30 \text { minutes } \\
30-60\end{array}$ & 160 & 43 \\
& $\begin{array}{l}\text { minutes } \\
>60 \text { minutes }\end{array}$ & 27 & 49.7 \\
\hline $\begin{array}{l}\text { Fear of COVID-19 at health } \\
\text { institutions }\end{array}$ & Yes & $\begin{array}{l}94 \\
278\end{array}$ & 7.3 \\
\hline
\end{tabular}

Table 4 Availability and Accessibility of Vaccination ServiceRelated Characteristics Among 12 to 23 Months at Assosa Town, Ethiopia, 2020

\begin{tabular}{|l|l|l|l|}
\hline Variables & Categories & Frequency & $\%$ \\
\hline Attained ANC Visit & Yes & 290 & 78 \\
& No & 82 & 28 \\
\hline Number of ANC Visit & Yes & 258 & 69.4 \\
& No & 114 & 30.6 \\
\hline Received TT vaccine & Yes & 303 & 81.5 \\
& No & 69 & 18.5 \\
\hline Number of TT injection & One times & 66 & 17.7 \\
& Two times & 220 & 59.7 \\
& Three times & 16 & 4.3 \\
& Zero times & 70 & 18.8 \\
\hline \multirow{2}{*}{ Place of delivery } & Health Facility & 276 & 74.2 \\
& Home & 96 & 25.8 \\
\hline
\end{tabular}

(74.2) of the mothers gave birth at health institutions and the rest $96(25.8 \%)$ were gave birth at home (Table 4).

\section{Knowledge of Mothers/Caretakers on Vaccine and Vaccine-Preventable Disease (VPD)}

The majority 351 (94.4\%) of the mothers reported that they heard about vaccination and only $21(5.6 \%)$ were did not heard about vaccination. From those mothers who were heard about vaccination, most of them 157 $(42.2 \%)$ got information from the health profession. Around 220 (59.1\%) of the respondents said that the objective of vaccination is prevention of diseases.

Three hundred twenty-nine (88.4\%) respondents think that vaccination will make their child sick (Table 5).

\section{Vaccination Coverage of Children Aged 12-23 Months}

From the total of 372 study participants, the coverage of full vaccination, partial vaccination, and non-vaccination was $71.77 \%, 16.67 \%$, and $11.56 \%$, respectively (Figure 1).

\section{Vaccination Coverage for Each Vaccine Type}

The coverage immunizations for full, partially vaccinated, and none vaccinated were $71.77 \%, 16.67 \%$, and $11.56 \%$, respectively. 
Table 5 Knowledge of Mothers/Caretakers on Vaccine Related Characteristics Among 12 to 23 Months at Assosa Town, Ethiopia, 2020

\begin{tabular}{|c|c|c|c|}
\hline Variables & Categories & Frequency & $\%$ \\
\hline $\begin{array}{l}\text { Do you hear about } \\
\text { vaccination }\end{array}$ & $\begin{array}{l}\text { Yes } \\
\text { No }\end{array}$ & $\begin{array}{l}351 \\
21\end{array}$ & $\begin{array}{l}94.4 \\
5.6\end{array}$ \\
\hline Way you heard & $\begin{array}{l}\text { Radio } \\
\text { TV } \\
\text { Friends } \\
\text { Schools } \\
\text { Health } \\
\text { Personals } \\
\text { Others } \\
\text { No }\end{array}$ & $\begin{array}{l}38 \\
31 \\
88 \\
33 \\
157 \\
4 \\
21\end{array}$ & $\begin{array}{l}10.2 \\
8.3 \\
23.7 \\
8.9 \\
42.2 \\
1.3 \\
5.4\end{array}$ \\
\hline Objects of Vaccination & $\begin{array}{l}\text { To prevent } \\
\text { disease } \\
\text { For specific } \\
\text { disease } \\
\text { For Child } \\
\text { health } \\
\text { Do not know } \\
\text { Others }\end{array}$ & $\begin{array}{l}220 \\
18 \\
107 \\
7 \\
20\end{array}$ & $\begin{array}{l}59.1 \\
4.8 \\
28.8 \\
1.9 \\
5.4\end{array}$ \\
\hline $\begin{array}{l}\text { Number of sessions for full } \\
\text { vaccination }\end{array}$ & $\begin{array}{l}\text { One } \\
\text { Two } \\
\text { Three } \\
\text { Four } \\
\text { Five }\end{array}$ & $\begin{array}{l}7 \\
7 \\
35 \\
62 \\
261\end{array}$ & $\begin{array}{l}1.9 \\
1.9 \\
9.4 \\
16.7 \\
70.2\end{array}$ \\
\hline $\begin{array}{l}\text { Age of child to begin } \\
\text { vaccination }\end{array}$ & $\begin{array}{l}\text { Just after birth } \\
\text { One month } \\
\text { after birth } \\
\text { After one year } \\
\text { I do not know }\end{array}$ & $\begin{array}{l}299 \\
35 \\
2 \\
36\end{array}$ & $\begin{array}{l}80.4 \\
9.4 \\
\\
0.5 \\
9.7\end{array}$ \\
\hline $\begin{array}{l}\text { Do you think vaccination will } \\
\text { make your child sick? }\end{array}$ & $\begin{array}{l}\text { Yes } \\
\text { No }\end{array}$ & $\begin{array}{l}43 \\
329\end{array}$ & $\begin{array}{l}11.6 \\
88.4\end{array}$ \\
\hline $\begin{array}{l}\text { Do you bring a sick child for } \\
\text { vaccination? }\end{array}$ & $\begin{array}{l}\text { Yes } \\
\text { No }\end{array}$ & $\begin{array}{l}57 \\
315\end{array}$ & $\begin{array}{l}15.3 \\
84.7\end{array}$ \\
\hline $\begin{array}{l}\text { Did your child take any } \\
\text { vaccination? }\end{array}$ & $\begin{array}{l}\text { Yes } \\
\text { No }\end{array}$ & $\begin{array}{l}11 \\
361\end{array}$ & $\begin{array}{l}3 \\
97\end{array}$ \\
\hline Do you have a card? & Yes & 372 & 100 \\
\hline
\end{tabular}

From all children, around $326(87.9 \%)$ took BCG. And most of them were taking OPV0 and the percentage of all other vaccines were gone reducing. The coverage of BCG, OPVO, PCV1, Penta 1, Rota1, and IPV are $326(87.9 \%), 316(84.9 \%), 310(83.3 \%), 310$ $(83.3 \%), 310(83.3 \%)$ and $284(76.3 \%)$, respectively (Figure 2).

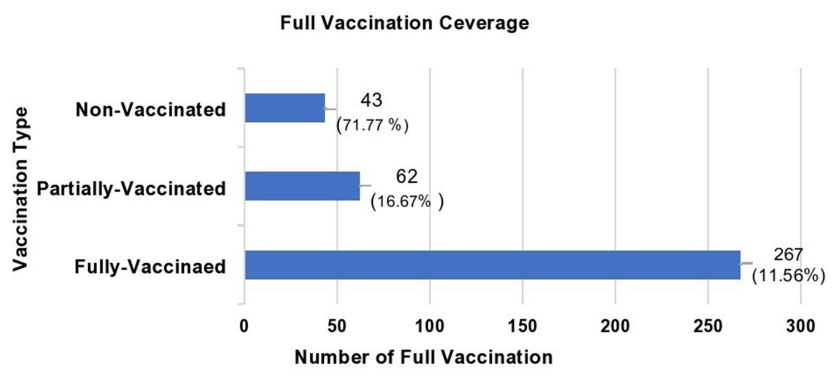

Figure I Bar graph to compare full, partial, and non-vaccination among 12 to 23 months at Assosa Town, Ethiopia, $2020(n=372)$.

\section{Reasons for Vaccination Failure Among} Never or Partially Vaccinated Children Reasons for Failure to Complete Full Vaccine

Those respondents who were partially vaccinated with their children were interviewed for reasons of failure to complete. Accordingly, the major reasons are fear of covid-19, lack of awareness, fear of side effects, and religious and cultural barriers which account $26(41.9 \%)$, $16(25.8 \%), 8(12.9 \%)$ and $6(9.7 \%)$ respectively are the main reasons for vaccine dropout (Table 6).

\section{Reasons for Not Ever Vaccinating Child}

Concerning the reason for not ever vaccinating their children, from the total children who were not ever vaccinated, the major reasons were fear of covid-19, lack of awareness and fear of side accounts 16 (37.2\%),16 $(37.2 \%)$ and $10(23.3 \%)$ respectively were the main reasons (Table 6).

\section{Factors Associated with Full Vaccination Status}

Based on the study conducted, child age, no ANC followup, and fear of covid 19 at the health institution were identified as significant factors for full vaccination (Table 7).

\section{Discussion}

The coverage of immunization for full, partially immunized, and non-immunized were $71.77 \%, 16.67 \%$, and $11.56 \%$, respectively.

This study assessed immunization coverage and factors associated with part and non-vaccination status among children aged between 12 and 23 months in Assosa Town. In this study, a total of 372 mothers/caretakers who have immunization card were interviewed and the response rate was $100 \%$.

Based on the findings of this research, the coverage of full vaccination was 267 (71.77\%). This finding was low where 


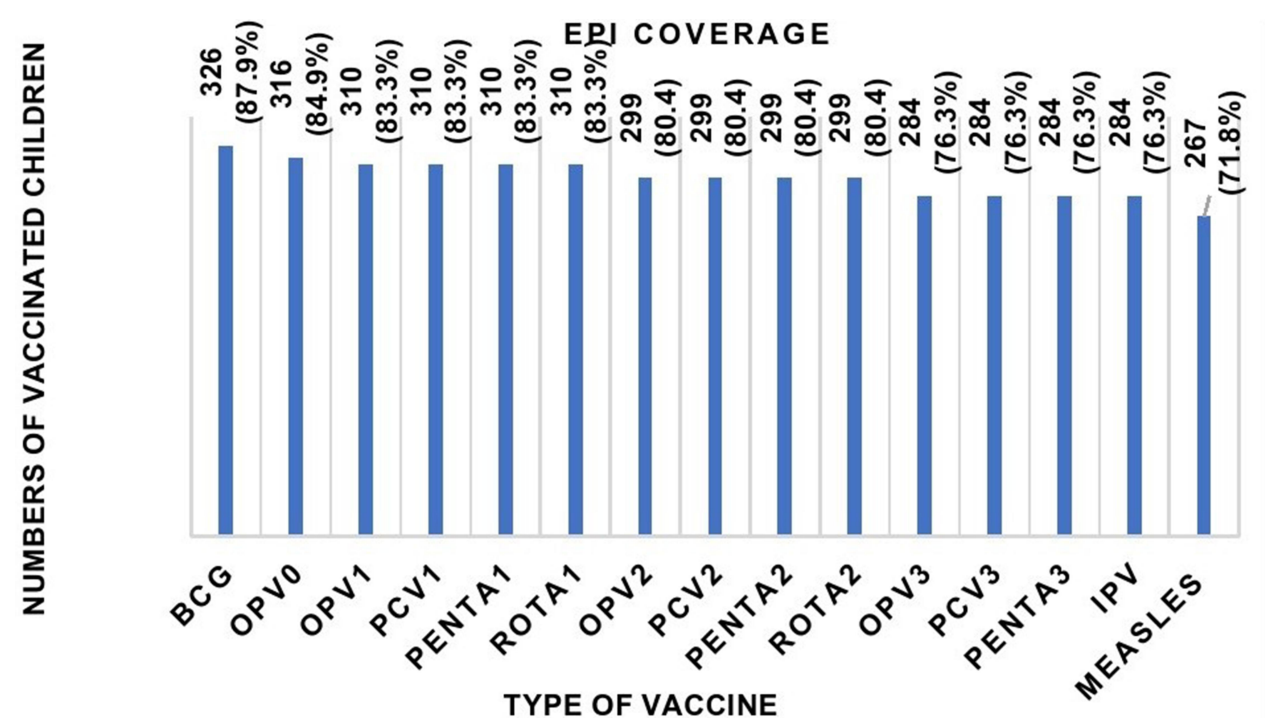

Figure 2 Bar graph shows EPI coverage among 12 to 23 months at Assosa Town, Ethiopia, 2020 (n=372).

compared with studies conducted in Amhara, Mercha district $(87.7 \%),{ }^{14}$ Amhara, Bahirdar town $(75.6 \%),{ }^{15}$ Minjar Shenkor district $(75.7 \%)^{16}$ Amhara, Debre Markos Town $(91.7 \%){ }^{12}$ Amhara Gondar city administration $(77.4 \%)^{17}$ and Tigray Sekota Zuria Woreda $(75.5 \%)^{18}$

This might be because of lack of awareness, fear of covid 19 at health institutions, fear of side effects, and religious and cultural barriers.

According to bivariate and multivariate logistic regression analysis, child age, no ANC visit, and fear of COVID 19 at health institutions were identified as significantly associated factors of full vaccination.

Children between 12 and 15 months of age were 2.7 times more likely to become incomplete immunization when compared to those of age from 20 to 23 months [AOR=2.7, 95\% CI: $(1.36,5.4)]$.
Children whose mothers did not have prenatal care visits (ANC) are less likely to receive full vaccination compared to mothers who had an ANC visit. This finding was consistent with the result obtained in Mizan Aman Town $^{19}$ to: The use of prenatal care encourages the use of subsequent maternal and child health services, like vaccination. $^{20}$

Children whose mothers had fear of COVID 19 at health institutions were 3.5 times more likely to have incomplete/non-immunization when compared with those mothers who had no fear of covid 19 at health institutions $[\mathrm{AOR}=3.5,95 \% \mathrm{CI}:(2,6)]$. This finding is in line with studies conducted in different areas.

In fact, this could be due to the risk of infection and the need to maintain physical distance in the early stages of the COVID-19 pandemic. Many countries have temporarily and

Table 6 Reasons for Vaccination Failure Among Partially and Non-Vaccinated Children Among 12 to 23 Months at Assosa Town, Ethiopia, 2020

\begin{tabular}{|l|l|l|l|l|l|l|l|l|l|l|}
\hline \multirow{2}{*}{ Reasons } & \multicolumn{3}{l|}{ Partial Vaccination } & \multicolumn{2}{l|}{ Total } & \multicolumn{2}{l|}{ Non Vaccinated } \\
\cline { 2 - 5 } & Yes & $\%$ & No & $\%$ & & Yes & $\%$ & No & $\%$ \\
\hline Sibling and twin related & 2 & 3.2 & 1 & 0.32 & 3 & 0 & 0 & 3 & 0.91 & 3 \\
Health worked did not come to give vaccine & 1 & 1.6 & 0 & 0 & 1 & 0 & 0 & 1 & 0.3 & 1 \\
Religious and cultural barrier & 6 & 9.7 & 1 & 3.22 & 7 & 1 & 2.32 & 6 & 1.82 & 7 \\
Lack of awareness & 16 & 25.8 & 17 & 5.48 & 33 & 16 & 37.2 & 17 & 5.16 & 33 \\
Fear of side effect & 8 & 12.9 & 10 & 3.22 & 18 & 10 & 23.25 & 8 & 2.43 & 18 \\
Fear of COVID 19 & 26 & 41.9 & 16 & 5.16 & 42 & 16 & 38.1 & 26 & 7.9 & 42 \\
Far distance & 3 & 4.84 & 0 & 0 & 3 & 0 & 0 & 3 & 0.91 & 3 \\
Total & 62 & 100 & 310 & 17.4 & 372 & 43 & 100 & 329 & 19.43 & 372 \\
\hline
\end{tabular}


Table 7 Bivariable and Multivariable Logistic Regression Analysis with p value Less Than 0.2

\begin{tabular}{|c|c|c|c|c|c|c|}
\hline \multirow[t]{2}{*}{ Variables } & \multirow[t]{2}{*}{ Category } & \multicolumn{2}{|c|}{ Full Vaccination } & \multirow[t]{2}{*}{ Crude OR $(95 \% \mathrm{Cl})$} & \multirow[t]{2}{*}{ Adjusted OR (95\% Cl) } & \multirow[t]{2}{*}{$P$ value } \\
\hline & & Yes & No & & & \\
\hline \multirow[t]{3}{*}{ Child Age in months } & $12-15$ & $116(63)$ & $68(37)$ & $2.5(1.3,4.8)$ & $2.7(1.36,5.4)$ & 0.005 \\
\hline & $16-19$ & $91(79.8)$ & $23(20.2)$ & I.I $(0.5,2.3$ & I.I $(0.5,2.4)$ & 0.82 \\
\hline & $20-23$ & $60(81.1)$ & $14(\mid 8.9)$ & 1 & 1 & I \\
\hline \multirow[t]{2}{*}{ Birth spacing } & $<2$ years & $133(68.8)$ & $61(31.4)$ & I & 1 & I \\
\hline & $>2$ years & $134(175.3)$ & $44(24.7)$ & $1.39(0.89,2.2)$ & I.4(0.87,2.34) & 0.17 \\
\hline \multirow[t]{2}{*}{ ANC follow-up } & Yes & $197(74.4)$ & $61(23.6)$ & I & 1 & I \\
\hline & No & $70(61.4)$ & $44(38.6)$ & $0.5(0.3,0.8)$ & $0.4 I(0.24,0.7 I)$ & 0.01 \\
\hline \multirow[t]{2}{*}{ Fear of COVID-19 at health institutions } & Yes & $50(53.2)$ & $44(46.8)$ & I & I & I \\
\hline & No & $207(78.1)$ & $6 I(21.9)$ & $3.13(1.9,5.1)$ & $3.5(2,6)$ & 0.001 \\
\hline \multirow[t]{2}{*}{ Place of delivery } & Yes & $207(75)$ & $69(25)$ & I & I & 1 \\
\hline & No & $60(62.5)$ & $36(37.5)$ & $0.06(0.34,0.91)$ & $0.06(0.34,1)$ & 0.6 \\
\hline \multirow[t]{2}{*}{ Accessibility of Health facility } & Yes & $266(72.1)$ & $103(27.9)$ & 1 & 1 & 1 \\
\hline & No & $I(33.3)$ & $2(66.7)$ & $0.19(0.017,2.16)$ & $0.3(0.02,4.5)$ & 0.4 \\
\hline
\end{tabular}

Abbreviations: $C O R$, crude odds ratio; $A O R$, adjusted odds ratio; $\mathrm{Cl}$, confidence interval.

adequately suspended mass preventive vaccination campaigns against vaccine-preventable diseases. ${ }^{21}$

The pool of un-immunized children is expanding during lockdown, leaving them susceptible to vaccine-preventable diseases. $^{22}$

In times of quarantine, vaccination activities in all age groups, especially routine vaccines for children, were interrupted, delayed, reorganized, or completely transferred to another time. Many developed, as well as undeveloped and developing countries, are now seeing rapid declines in childhood vaccination rates. ${ }^{23}$

Covid 19 affects health care delivery like vaccination programs. ${ }^{24}$

Strategies like stay-at-home, social distancing results in decreased accessibility to routine immunization services and make children at risk for vaccine preventable-diseases and also its complications. ${ }^{25}$

The mitigation measures adopted to control the COVID-19 pandemic threaten to undo the progress achieved in the control of vaccine-preventable diseases in low- and middle-income countries and high-income countries. $^{26}$

From the major reasons for vaccination failure among partially vaccinated children; there are religious and cultural barriers that account $6(9.7 \%)$ of all reasons. This might be due to missed understanding or miss interpretation of religious and cultural concepts or views of child vaccination. Therefore, to improve vaccination coverage and to decrease the missing of their children's vaccination, government of the region need to do with religious leaders, community elders, health extension workers, and other concerned bodies.

\section{Strength and Limitations of the Study Strength of the Study}

Since there was a shortage of data related to immunization coverage and factors associated with under vaccine in this area, this finding might be an additional resource for those stakeholders who want to do any more implementation. And they were different new variables added to this study like fear of covid 19 at health institutions, injectable polio vaccine (IPV), and rota.

\section{Limitations of the Study}

Immunization coverage might have been underreported or overreported by mothers/caretakers may not remember vaccines that the child took due to recall bias. As a consequence, recall bias may affect the quality of data. Moreover, there might be the potential for selection bias while selecting households and choosing children from those households with more than one child during data collection time. And those mothers or care givers who did not live for less than 12 months were excluded from the study. 


\section{Conclusions and Recommendations}

Coverage of full vaccination, partial vaccination, and nonvaccination were $71.77 \%, 16.67 \%$, and $11.56 \%$ not vaccinated, respectively. Child age, no antenatal care visit, and fear of covid 19 at health institutions were identified as significant factors. The major reasons for partial immunization and non-immunization were fear of covid-19, lack of awareness, fear of side effect, and religious and cultural barriers.

It is also recommended that the Assosa town health office, Regional Health Bureau, and Woreda health office need to do with health care providers in supporting of EPI officer, EPI focal at health centers, and hospitals and health extension workers. Better to do more on awareness creation on immunization side effects, covid 19, timely vaccination, ANC and traditional and cultural beliefs of immunization to vaccinate their children fully.

\section{Abbreviations}

ANC, Ante Natal Care; BCG, Bacillus Calmette-Guerin; COVID 19, Corona Virus Disease 2019; DPT, Diphtheria Pertussis and Tetanus; EDHS, Ethiopia Demographic Health Survey; EPI, Expanded Program on Immunization; FMOH, Federal Ministry of Health; HBV, Hepatitis B Virus; HIB, Haemophilus Influenza Type B; IPV, Inactivated Polio Vaccine; OPV, Oral Polio Virus; U5MR, Under Five Mortality Rate; WHO, World Health Organization; SPSS, Statistical Program for the Social Sciences.

\section{Acknowledgments}

First, We would like to give our hearts full thanks to our data collectors, participants, administratives of each woreda and kebele for their collaborative work and response. And we would like to say thanks to Assosa University, college of health science department of public health.

\section{Author Contributions}

MS, FA, ES and MW: All authors made a significant contribution to the work reported, whether that is, in the conception, study design, execution, acquisition of data, analysis and interpretation, or in all these areas; took part in drafting, revising or critically reviewing the article; gave final approval of the version to be published; have agreed on the journal to which the article has been submitted; and agree to be accountable for all aspects of the work.

\section{Disclosure}

The authors declare no conflicts of interest for this work and that there are no conflicts of interest regarding the publication of this paper.

\section{References}

1. What is immunization?. Available from: http://www.who.int/topics/ immunization/en/. Accessed February 4, 2021.

2. Wolfson LJ, Gasse F, Lee-Martin S-P, et al. Estimating the costs of achieving the WHO-UNICEF Global Immunization Vision and Strategy, 2006-2015. Bull World Health Organ. 2008;86:27-39. doi:10.2471/BLT.07.045096

3. FMoH. Ethiopia national expanded program on immunization: comprehensive multi-year plan 2010-2014. Federal Ministry of Health: Addis Ababa; 2019. Available from: http://www.moh.gov.et/ resources. Accessed May 26, 2021.

4. Ethiopian Public Health Institute (EPHI) [Ethiopia] and ICF. Ethiopia Mini Demographic and Health Survey 2019: Key Indicators. Rockville, ML, USA: EPHI and ICF; 2019.

5. Feldstein LR, Mariat S, Gacic-Dobo M, Diallo MS, Conklin LM, Wallace AS. Global routine vaccination coverage, 2016. MMWR Morb Mortal Wkly Rep. 2017;66(45):1252. doi:10.15585/mmwr.mm6645a3

6. Odusanya OO, Alufohai EF, Meurice FP, Ahonkhai VI. Determinants of vaccination coverage in rural Nigeria. BMC Public Health. 2008;8 (1):1-8. doi:10.1186/1471-2458-8-381

7. Buonsenso D, Cinicola B, Kallon MN, Iodice F. Child healthcare and immunizations in sub-Saharan Africa during the COVID-19 pandemic. Front Pediatrics. 2020;8:517. doi:10.3389/fped.2020.00517

8. Marotta C, Di Gennaro F, Pizzol D, et al. The at risk child clinic (ARCC): 3 years of health activities in support of the most vulnerable children in Beira, Mozambique. Int J Environ Res Public Health. 2018;15(7):1350. doi:10.3390/ijerph15071350

9. World Health Organization. Progress towards measles control in WHO's African Region, 2001-2008. Weekly Epidemiological Record. 2009;84(39):397-404

10. Tilahun B, Teklu A, Mancuso A, Abebaw Z, Dessie K, Zegeye D. How can the use of data within the immunisation programme be increased in order to improve data quality and ensure greater accountability in the health system? A protocol for implementation science study. Health Res Policy Sys. 2018;16(1):1-6. doi:10.1186/s12961-018-0312-2

11. Eshete A, Shewasinad S, Hailemeskel S. Immunization coverage and its determinant factors among children aged 12-23 months in Ethiopia: a systematic review, and Meta-analysis of cross-sectional studies. $B M C$ Pediatr. 2020;20:1-13. doi:10.1186/s12887-020-02163-0

12. Mesfin M. Incomplete Vaccination and Associated Factors Among Children Aged 12-23 Months in Yirgalem Town. South Ethiopia: Addis Ababa University; 2015.

13. Workina A, Seid S, Moga T. Reason for incomplete vaccination and associated factors among children aged 12-23 months in Serbo Town, Jimma Zone, Oromia Region, Southwest Ethiopia. Adv Res $J$ Multidis Discov. 2018;32(14):79-84.

14. Yimer M, Abera B, Mulu W, Bezabih B. Knowledge, attitude and practices of high risk populations on louse-borne relapsing fever in Bahir Dar city, north-west Ethiopia. Sci J Public Health. 2014;2 (1):15-22. doi:10.11648/j.sjph.20140201.13

15. Tesfaye TD, Temesgen WA, Kasa AS. Vaccination coverage and associated factors among children aged 12-23 months in Northwest Ethiopia. Hum Vaccin Immunother. 2018;14(10):2348-2354. doi:10.1080/21645515.2018.1502528

16. Mekonnen AG, Bayleyegn AD, Ayele ET. Immunization coverage of 12-23 months old children and its associated factors in MinjarShenkora district, Ethiopia: a community-based study. $B M C$ Pediatr. 2019;19(1):1-8. doi:10.1186/s12887-019-1575-7 
17. Yismaw AE, Assimamaw NT, Bayu NH, Mekonen SS. Incomplete childhood vaccination and associated factors among children aged 12-23 months in Gondar city administration, Northwest, Ethiopia 2018. BMC Res Notes. 2019;12(1):1-7. doi:10.1186/s13104-019-4276-2

18. Girmay A, Dadi AF. Full immunization coverage and associated factors among children aged 12-23 months in a hard-to-reach areas of Ethiopia. Int J Pediatr. 2019;2019:2019. doi:10.1155/2019/1924941

19. Meleko A, Geremew M, Birhanu F. Assessment of child immunization coverage and associated factors with full vaccination among children aged 12-23 months at Mizan Aman town, bench Maji zone, Southwest Ethiopia. Int $J$ Pediatr. 2017;2017:2017. doi: $10.1155 / 2017 / 7976587$

20. Mishra V, Retherford RD. The effect of antenatal care on professional assistance at delivery in rural India. Popul Res Policy Rev. 2008;27 (3):307-320. doi:10.1007/s11113-007-9064-3

21. World Health Organization. At least 80 million children under one at risk of diseases such as diphtheria, measles and polio as COVID-19 disrupts routine vaccination efforts, warn Gavi, WHO and UNICEF. WHO and UNICEF[Online]; 2020. Available from: https://www. whoint/news-room/detail/22-05-2020-at-least-80-million-childrenunder-one-at-risk-of-diseases-such-as-diphtheria-measles-and-polioas-covid-19-disrupts-routine-vaccination-efforts-warn-gavi-who-andunicef. Accessed May 26, 2021.
22. Chandir S, Siddiqi DA, Mehmood M. Impact of COVID-19 pandemic response on uptake of routine immunizations in Sindh, Pakistan: an analysis of provincial electronic immunization registry data. Vaccine. 2020;38(45):7146.

23. Dinleyici EC, Borrow R, Safadi MAP, van Damme P, Munoz FM. Vaccines and routine immunization strategies during the COVID-19 pandemic. Hum Vaccin Immunother. 2020;1-8.

24. Santoli JM, Lindley MC, DeSilva MB. Effects of the COVID-19 pandemic on routine pediatric vaccine ordering and administrationUnited States, 2020. MMWR Morb Mortal Wkly Rep. 2020;69(19):69. doi:10.15585/mmwr.mm6919e2

25. Bramer CA, Kimmins LM, Swanson R, et al. Decline in child vaccination coverage during the COVID-19 pandemic-Michigan Care Improvement Registry, May 2016-May 2020. Am J Transplant. 2020;20(7):1930. doi:10.1111/ajt.16112

26. Olorunsaiye CZ, Yusuf KK, Reinhart K, Salihu HM. COVID-19 and Child Vaccination: a Systematic Approach to Closing the Immunization Gap. Int J Maternal Child Health AIDS. 2020;9 (3):381.

\section{Publish your work in this journal}

Pediatric Health, Medicine and Therapeutics is an international, peerreviewed, open access journal publishing original research, reports, editorials, reviews and commentaries. All aspects of health maintenance, preventative measures and disease treatment interventions are addressed within the journal. Practitioners from all disciplines are invited to submit their work as well as healthcare researchers and patient support groups. The manuscript management system is completely online and includes a very quick and fair peer-review system. Visit http://www.dovepress.com/testimonials.php to read real quotes from published authors. 